\title{
Detection of Tick-Borne Pathogens in the Korean Water Deer (Hydropotes inermis argyropus) from Jeonbuk Province, Korea
}

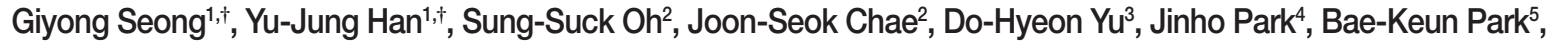 \\ Jae-Gyu Yoo ${ }^{6}$, Kyoung-Seong Choi',** \\ ${ }^{1}$ College of Ecology and Environmental Science, Kyungpook National University, Sangju 37224, Korea; ${ }^{2}$ Laboratory of Veterinary Internal Medicine, \\ BK21 PLUS Program for Creative Veterinary Science Research, Research Institute for Veterinary Science and College of Veterinary Medicine, Seoul \\ National University, Seoul 08826, Korea; ${ }^{3}$ College of Veterinary Medicine, Chonnam National University, Gwangju 61186, Korea; ${ }^{4}$ College of \\ Veterinary Medicine, Chonbuk National University, Iksan 54596, Korea; ${ }^{5}$ College of Veterinary Medicine, Chungnam National University, Daejoen \\ 34134, Korea; 'aboratory of Veterinary Clinics, National Institute of Animal Science Rural Development Administration, Jeonju 54875, Korea
}

\begin{abstract}
The objective of this study was to investigate the prevalence of tick-borne pathogens in the Korean water deer (Hydropotes inermis argyropus). Pathogens were identified using PCR which included Anaplasma, Ehrlichia, Rickettsia, and Theileria. Rickettsia was not detected, whereas Anaplasma, Ehrlichia, and Theileria infections were detected in 4, 2, and 8 animals, respectively. The most prevalent pathogen was Theileria. Of the 8 Theileria-positive animals, 2 were mixedinfected with 3 pathogens (Anaplasma, Ehrlichia, and Theileria) and another 2 animals showed mixed-infection with 2 pathogens (Anaplasma and Theileria). Sequencing analysis was used to verify the PCR results. The pathogens found in this study were identified as Anaplasma phagocytophilum, Ehrlichia canis, and Theileria sp. To the best of our knowledge, this is the first report identifying these 3 pathogens in the Korean water deer. Our results suggest that the Korean water deer may serve as a major reservoir for these tick-borne pathogens, leading to spread of tick-borne diseases to domestic animals, livestock, and humans. Further studies are needed to investigate their roles in this respect.
\end{abstract}

Key words: Anaplasma, Ehrlichia, Theileria, tick-borne pathogen, Korean water deer, reservoir

Tick infestations in animals are of increasing concern, mainly because the epidemiology and geographical distribution of these infestations are constantly changing due to climate change, abundance of wildlife animals as hosts, and decrease in environmental biodiversity [1]. As a result, the incidence of tick-borne diseases (TBDs) has increased [2]. Anaplasmosis and theileriosis, considered to be the most important TBDs, have resulted in animal health problems and extensive economic losses causing management-related problems in the livestock industry [3,4]. However, there have been relatively few studies on tick-borne pathogens from wild ungulates in Korea [5-7], and therefore, little information is available on how infections caused by these pathogens might affect the population.

\footnotetext{
- Received 1 June 2015, revised 10 August 2015, accepted 14 August 2015.

*Corresponding author (kschoi3@knu.ac.kr)

${ }^{\dagger}$ These authors contributed equally to this work.

(c) 2015, Korean Society for Parasitology and Tropical Medicine

This is an Open Access article distributed under the terms of the Creative Commons Attribution Non-Commercial License (http://creativecommons.org/licenses/by-nc/3.0) which permits unrestricted non-commercial use, distribution, and reproduction in any medium, provided the original work is properly cited.
}

Korean water deer (Hydropotes inermis argyropus) are one of the most widely distributed wild ungulates in Korea, and are known to be important natural reservoir hosts of TBDs $[5,6]$. The Korean water deer has been classified as a vulnerable species and included in the International Union for Conservation of Nature and Natural Resources Red List, due to a serious decline in their population as a result of poaching and habitat destruction [8]. Recently, however, wild Korean water deer populations have been growing in Korea [9], and because of their close proximity to domestic animals, they may act as a disease transmission of tick-borne pathogens to these animals. Therefore, the objective of this study was to investigate the pathogens of TBDs in Korean water deer and to evaluate their roles as potential reservoirs for TBDs circulating in Korea.

The capture of wild Korean water deer and sample collection were performed with permission from the Wildlife Rescue Center located in the Jeonbuk Province, Korea. Between March and June 2014, 5 animals were captured and whole blood samples were collected. Five more animals were killed in the traffic accidents, found dead and transferred to the Wildlife 
Rescue Center by local residents, and their spleens were collected. No ticks were found in the first 5 animals. The blood samples and spleens were immediately frozen at $-80^{\circ} \mathrm{C}$ until DNA extraction was performed.

Genomic DNA was extracted from whole blood and spleen samples using a DNeasy Blood and Tissue Kit (Qiagen, Valencia, California, USA) according to the manufacturer's instructions. Diagnosis of Theileria infection was performed using an AccuPower ${ }^{\circledR}$ Theileria PCR kit (Bioneer, Daejeon, Korea) using 2 specific primer sets targeting the $18 \mathrm{~S}$ ribosomal RNA (F, 5'-GTTATAAATCGCAAGGAAGTTTAAGGC-3'; R, 5'-GTGTACAAAGGGCAGGGACGTA- $3^{\prime}$ ). The predicted size of the amplified PCR product was 239 bp under the following cycling conditions: $94^{\circ} \mathrm{C}$ for $5 \mathrm{~min}$, followed by 40 cycles of $94^{\circ} \mathrm{C}$ for $20 \mathrm{sec}$ and $65^{\circ} \mathrm{C}$ for $35 \mathrm{sec}$, and a final extension of $72^{\circ} \mathrm{C}$ for 5 min. AccuPower ${ }^{\circledR}$ Rickettsiales 3-Plex PCR kit (Bioneer) was used to detect Anaplasma (F, 5'- TACCTCTGTGTTGTAGCTAACGC-3'; R, 5'-CTTGCGACATTGCAACCTATTGT-3'), Ehrlichia (F, 5'-CGGAATTCCTAGTGTAGAGG-3'; R, 5'-AGGAGGGATACGACCTTC AT-3'), and Rickettsia (F, 5'-TAGGGGATGATGGAATTCCTA-3'; R, 5'-CCCCCGTCA ATTCCTTTGAG-3'). These PCRs were performed using specific primer sets that targeted the 16S ribosomal RNA. The predicted sizes of the amplified PCR products for Anaplasma, Ehrlichia, and Rickettsia were 429 bp, $340 \mathrm{bp}$, and $252 \mathrm{bp}$, respectively, under the following cycling conditions: $95^{\circ} \mathrm{C}$ for $15 \mathrm{~min}$, followed by 40 cycles of $95^{\circ} \mathrm{C}$ for $10 \mathrm{sec}, 58^{\circ} \mathrm{C}$ for $30 \mathrm{sec}$, and $72^{\circ} \mathrm{C}$ for $30 \mathrm{sec}$, and then a final extension of $72^{\circ} \mathrm{C}$ for $5 \mathrm{~min}$. PCR products were separated by gel electrophoresis on 1.5\% agarose gels and visualized by staining with ethidium bromide.

The PCR products were purified with a QIAquick PCR purification kit (Qiagen). The nucleotide sequences were determined by direct sequencing of the PCR products using a BigDye terminator cycle sequencing kit (Applied Biosystems, Foster City, California, USA) and analyzed on an ABI PRISM ${ }^{\circledR}$ DNA analyzer (Applied Biosystems). The sequence data were aligned using the Clustal X (version 1.8) [10]. Additional sequences from representative isolates of anaplasmosis, ehrlichiosis, and theileriosis were obtained from the GenBank database and included with each set of alignments. A phylogenetic tree based on nucleotide alignments was constructed using the neighbor-joining method [11]. Bootstrap analysis was carried out using 1,000 replications, and the tree was visualized using Treeview [12].

The prevalence of TBD pathogens was analyzed from blood
Table 1. Summary of tick-borne pathogens detected from Korean water deer by PCR in this study

\begin{tabular}{lccccc}
\hline Sample no. & Specimen & Anaplasma & Ehrlichia & Rickettisa & Theileria \\
\hline 1 & Blood & - & - & - & + \\
2 & Blood & - & - & - & - \\
3 & Spleen & - & - & - & - \\
4 & Spleen & - & - & - & + \\
5 & Spleen & + & - & - & + \\
6 & Blood & + & - & - & + \\
7 & Blood & + & + & - & + \\
8 & Spleen & + & + & - & + \\
9 & Spleen & - & - & - & + \\
10 & Blood & - & - & - & + \\
\hline
\end{tabular}

"+", positive; "-", negative.

and spleen samples of 10 Korean water deer by PCR (Table 1). Of the 10 animals, 4 were positive for Anaplasma infection, and 2 were positive for Ehrlichia infection, and 8 were positive for Theileria infection. Also, of these animals, 2 were found to have mixed-infections with 2 pathogens (Anaplasma and Theileria, $\mathrm{n}=2$ ) and another 2 animals were found to have mixedinfections with 3 pathogens (Anaplasma, Ehrlichia, and Theileria, $\mathrm{n}=2$ ) (Table 1). Rickettsia spp. were not detected in any of the samples. According to our results, Theileria infection is the most prevalent in wild Korean water deer. These results demonstrate the possibility that wild Korean water deer may serve as a major reservoir for these TBD pathogens.

PCR analysis revealed that 4 animals were positive for infection with Anaplasma (Table 1). The nucleotide sequences of the 4 amplified samples showed 100\% identity, and we submitted 1 sequence to GenBank (accession no. KR045609). Anaplasma infections in the Korean water deer were determined to be of the species, A. phagocytophilum. Phylogenetic analysis revealed that the Korean isolate (KR045609) detected in this study was in the same clade as US human isolates, a Swedish horse isolate, a wild game isolate, a brown bear isolate, and tick isolates from several different countries, which showed $98.7-99.5 \%$ identity to each other. However, isolates from small ruminants (KJ183079, KF569916, and JN558816) and deer (AB196720 and AB196721) were identified as belonging to a different clade (Fig. 1). Interestingly, A. phagocytophilum identified in Chinese cattle (KF569910) was distinct from all other isolates.

Ehrlichia canis infections were found in 2 Korean water deer. Two amplicons were sequenced on both strands, and then aligned and analyzed for sequence identity. The 2 isolates were $100 \%$ identical, and we submitted 1 sequence to the GenBank (accession no. KR045610). The Korean isolate (KR045610) 


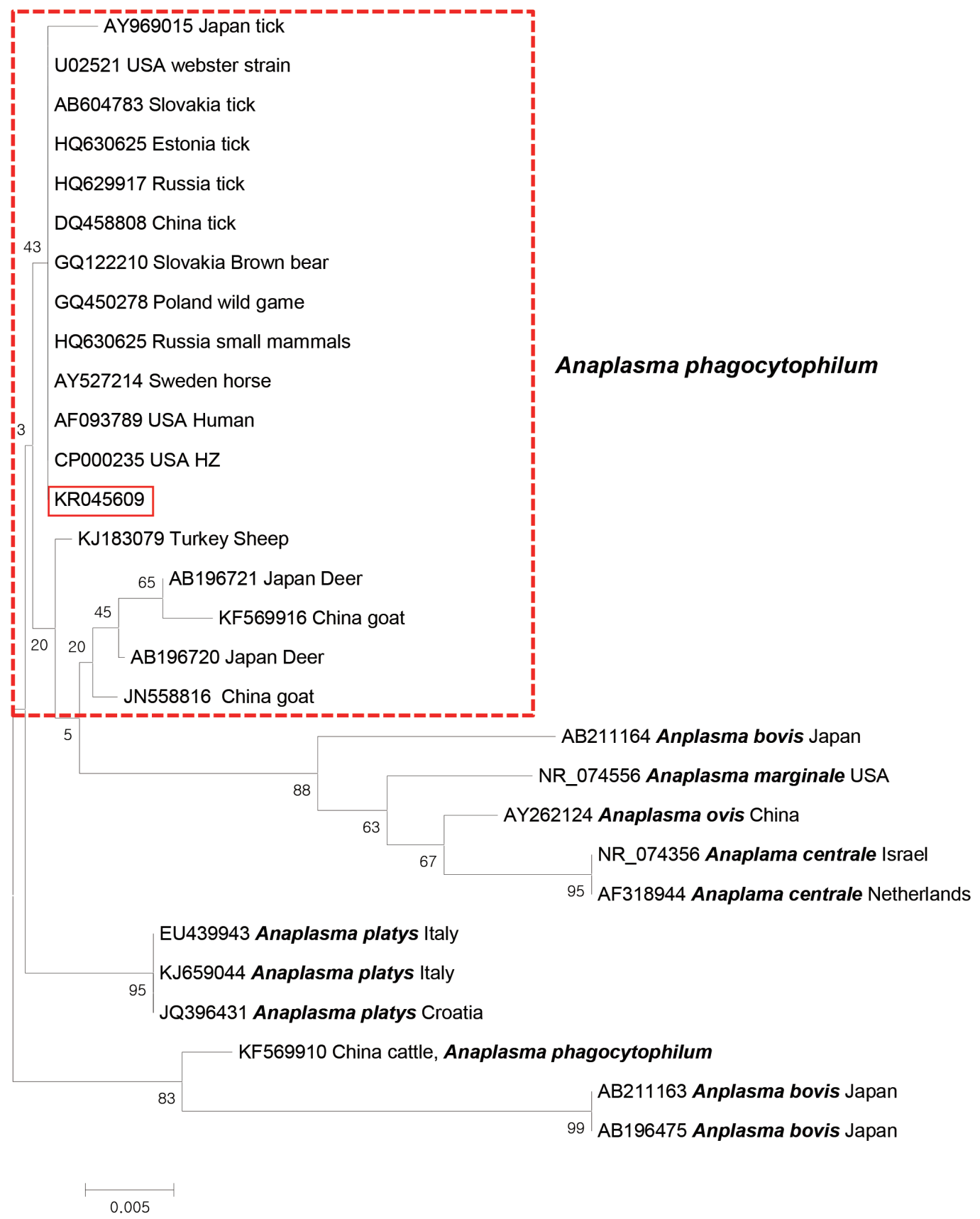

Fig. 1. Phylogenetic analysis of $16 \mathrm{~S}$ rRNA genes of Anaplasma phagocytophilum identified in Korean water deer. The red-faced box indicates the sequence determined in this study. Bootstrapping was carried out using 1,000 replications.

showed 98.6-98.9\% homology in nucleotide sequences with E. canis isolates from humans, dogs, and ticks, and 97.5-98.2\% homology with E. ruminantium by sequencing comparison. Phylogenetic analysis of the 16S rRNA gene revealed that the KR045610 isolate identified in this study belongs to the same clade as the previously reported E. canis strains, and is closely related to isolates from ticks in Japan (Fig. 2). KR045610 be- longs to a different clade with E. ruminantium, E. muris, and $E$. chaffensis, which is completely separate from Ehrlichia sp.

Of the 8 Theileria-positive animals, we randomly selected 3 PCR-positive samples for partial sequencing of the 18S rRNA genes, and found that these newly identified sequences shared $99.8 \%$ homology. Based on sequencing analysis of the $18 \mathrm{~S}$ rRNA, there were no obvious differences in the nucleotide se- 


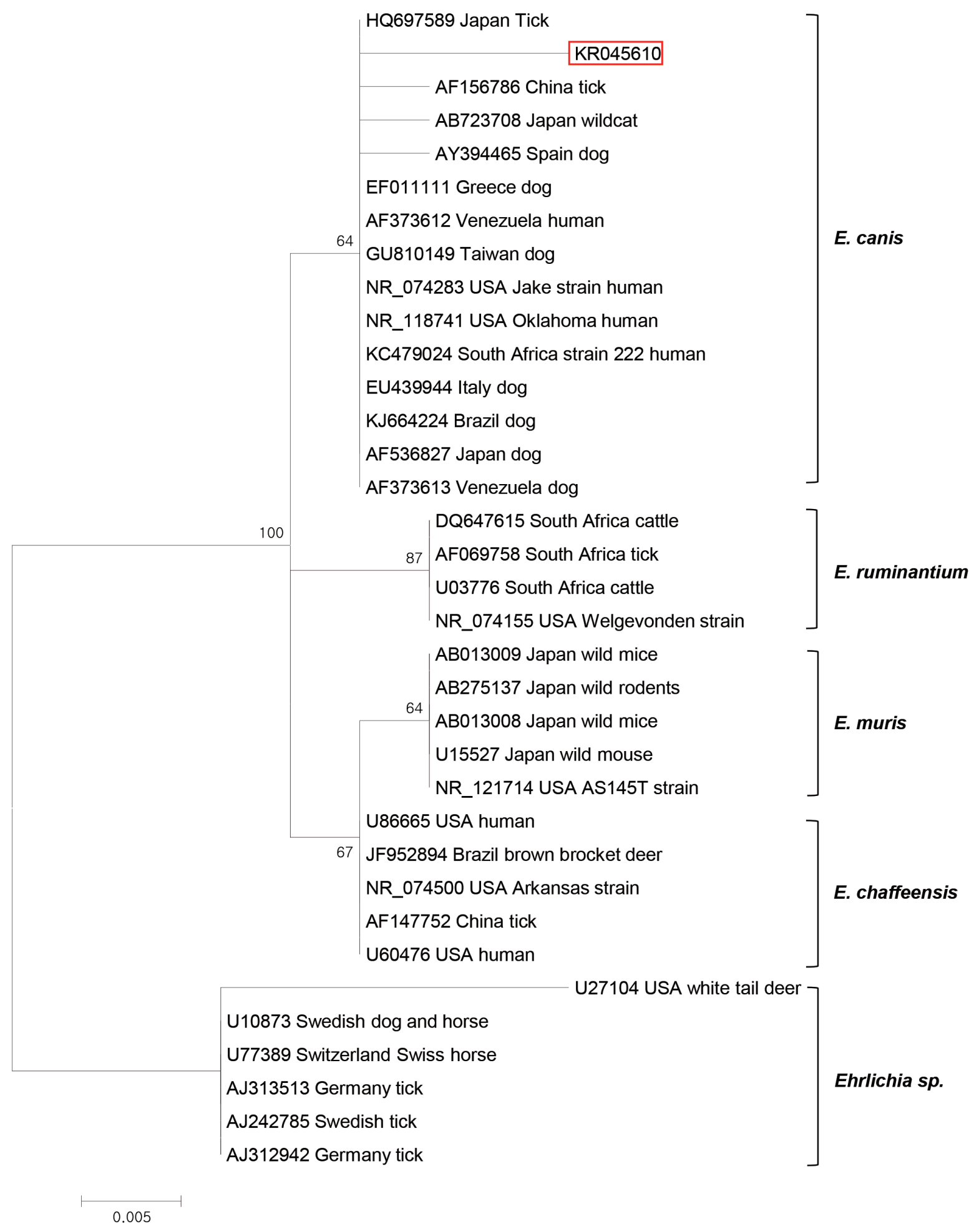

Fig. 2. Phylogenetic analysis of $16 \mathrm{~S}$ rRNA genes of Ehrlichia canis identified in Korean water deer. The red-faced box indicates the sequence determined in this study. Bootstrapping was carried out using 1,000 replications.

quences between Theileria sp. and T. luwenshuni. The phylogenetic tree showed that the 3 isolates (KT261643-KT2616445) obtained in this study were classified as Theileria sp., and were identical to the Theileria sp. from small ruminants and wild 


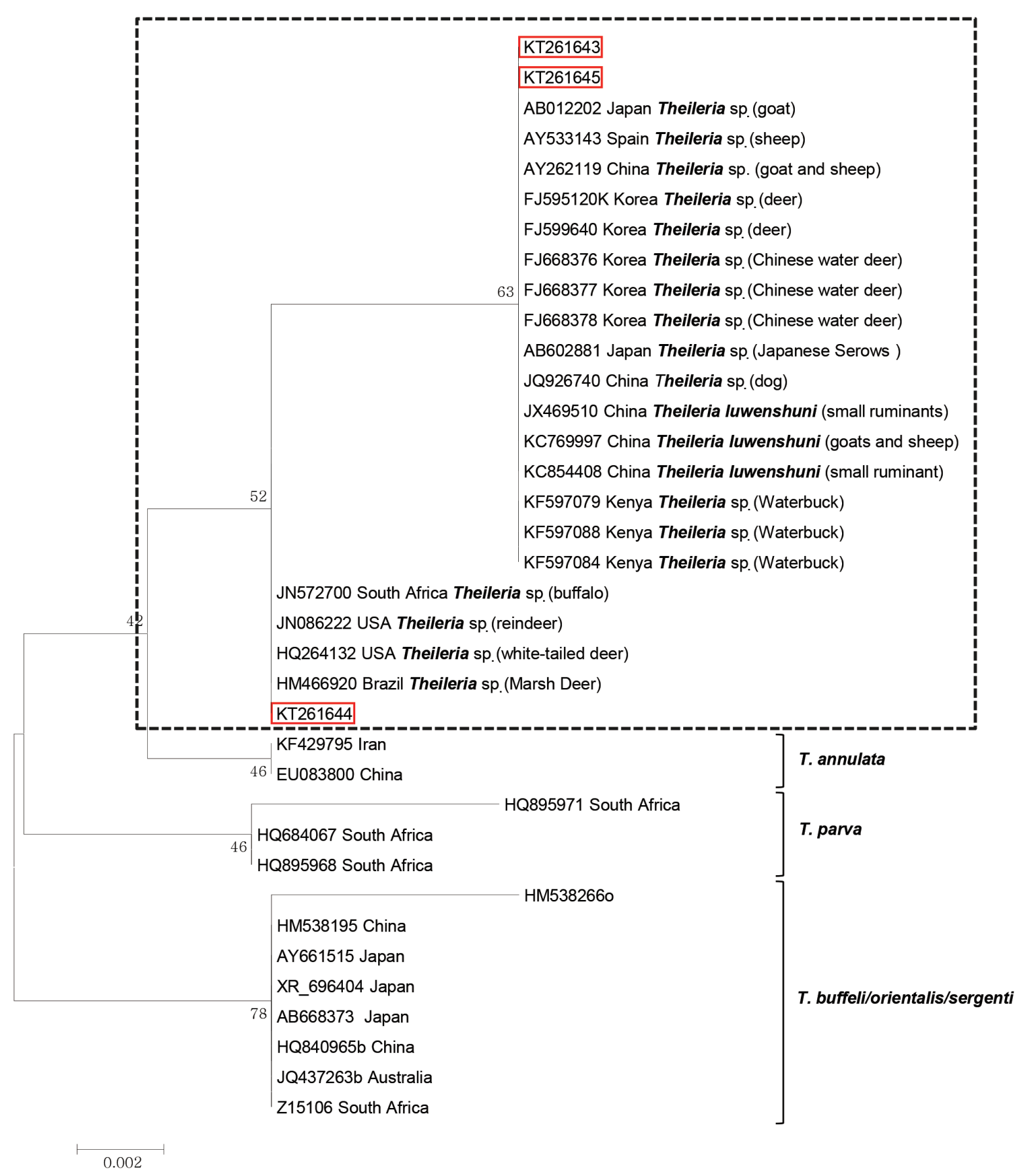

Fig. 3. Phylogenetic analysis based on the alignment of 18S rRNA gene sequences of Theileria sp. detected in Korean water deer, together with previously registered sequences from Theileria sp. The unrooted phylogenetic tree was constructed using neighbor-joining method. Bootstrapping was carried out using 1,000 replications. The 18S rRNA gene sequences identified in this study are shown in red-faced type.

ungulates in several countries, including China, Japan, Spain, and Kenya. Two (KT261643 and KT261645) of 3 isolates were in the same clade as T. luwenshuni (Fig. 3), and were similar to Theileria sp. of the wild Chinese water deer that had been iso- lated in Korea [13]. One isolate (KT261644) was divergent from the other 2 isolates and belonged to the same group as Theileria sp. isolated from wild ungulates of USA, Brazil, and South Africa. However, these isolates were obviously different 
from other species of Theileria such as T. buffeli/orientalis/sergenti and T. annulata/parva.

Korean water deer populations have been growing to the extent that they are now commonly found even in urban areas. This has led to disturbances, of varying degrees, to the human and livestock populations in Korea. Several studies have demonstrated that Korean water deer may be infected with Anaplasma spp. and Bartonella spp. [5,6]. So far, very little is known about the incidences of TBDs in Korean water deer in Korea. The present study reports the prevalence of TBDs in the Korean water deer. Using PCR, we demonstrated that mixed-infections of 2 species of pathogens (A. phagocytophilum and Theileria sp.), and 3 species of pathogens (A. phagocytophilum, E. canis, and Theileria sp.) were found in Korean water deer, and that Theileria sp. is the most prevalent pathogen. This is the first study, to our knowledge, reporting A. phagocytophilum, E. canis, and Theileria sp. infections in the Korean water deer. This indicates that Korean water deer may be a reservoir for transmission of TBDs to domestic animals and livestock.

The results of the present study demonstrate that $A$. phagocytophilum infections are the second most prevalent in the Korean water deer. Phylogenetic analysis indicated that the KR045609 isolate identified in this study was found to be more closely related to isolates from humans and ticks, rather than isolates from Asian small ruminants. In addition, $16 \mathrm{~S}$ rRNA gene sequencing showed that human and tick isolates including KR045609 were almost identical. A. phagocytophilum has been reported to be present in various animals, as well as in ticks [14-16]. A. phagocytophilum infection found in the Korean water deer in this study may have been a result of tick bites or contact with other animals. These results suggest that Korean water deer play a role in the natural maintenance cycle of A. phagocytophilum and increase the chances of this infection being transmitted to humans. Consequently, Korean water deer may act as an important host for the transmission of $A$. phagocytophilum infection, and therefore are a potential threat to animals, livestock, and humans.

E. canis causes canine monocytic ehrlichiosis, which is transmitted by Rhipicephalus sanguineus commonly known as the brown dog tick [17]. R. sanguineus ticks, which can be found on wild mammals, represents a major threats to dogs, felids, and humans $[18,19]$. According to several studies, E. canis infection has been detected mostly in blood samples from carnivores [19-22]. However, in this study, E. canis was detected in the Korean water deer, a wild ungulate, for the first time. Phy- logenetic analysis revealed KR045610 was closely related to a tick isolate from Japan. This indicates that there may be a tick that transmits E. canis in Korea, and consequently, the E. canis infections in the Korean water deer may be a result of tick bites. Further investigation is needed to identify the species of tick that is responsible for transmitting E. canis to Korean water deer, and more epidemiological surveys of wild animals will be needed to understand the ecology of this zoonotic pathogen.

In this study, we identified that Theileria infections are the most prevalent in Korean water deer by PCR analysis of the $18 \mathrm{~S}$ rRNA gene. The phylogenetic tree showed that all of the newly isolated, unidentified Theileria were classified as Theileria sp. These isolates belonged to 2 different clades. KT261643 and KT261645 were identical to those from small ruminants and wild ungulates, including the waterbuck, Chinese water deer, and deer; KT261644 was closely related to isolates from the deer and buffalo. These results suggest that there are at least 2 species of Theileria sp. circulating among Korean water deer in Korea. The Theileria sp. found in China (AY262119) is considered to be highly pathogenic in sheep [23] and is identical to 2 of our isolates. This finding raises the possibility that pathogenic Theileria sp. may be present in Korean water deer, posing a threat to small ruminants.

These results expand our knowledge of the prevalence of tick-borne pathogens. The present work emphasizes the role of Korean water deer in the dissemination of livestock pathogens. Since infected Korean water deer share the same home ranges as cattle and other domestic animals, the causative pathogens of TBDs may be transmitted to domestic animals, livestock, and humans through infected tick bites. Korean water deer are the most commonly rescued wild animal in Korea, and recently their population has been growing, resulting in increased contact with both humans and domestic animals. Human TBDs are often transmitted by domestic animals, such as cattle and goats, rather than wild animals. Our results indicate the significance of Korean water deer as a reservoir host for pathogens that can cause severe TBDs in domestic animals, livestock, and humans. The role of Korean water deer as a reservoir host for TBDs and their effect on public health should be investigated further in Korea.

\section{ACKNOWLEDGMENTS}

This work was carried out with the support of Cooperative 
Research Program for Agriculture Science and Technology Development (project no. PJ010092), Rural Development Administration, the Republic of Korea.

\section{CONFLICT OF INTEREST}

We declare that we have no conflicts of interest.

\section{REFERENCES}

1. Taylor MA. Emerging parasitic diseases of sheep. Vet Parasitol 2012; 189: 2-7.

2. Dantas-Torres F, Chomel BB, Otranto D. Ticks and tick-borne diseases: a one health perspective. Trends Parasitol 2012; 28: 437-446.

3. Uilenberg G. Importance of ticks and tick-borne diseases of domestic ruminants in Southern Europe. Parassitologia 1999; 41: 107-109.

4. Eygelaar D, Jori F, Mokopasetso M, Sibeko KP, Collins NE, Vorster I, Troskie M, Oosthuizen MC. Tick-borne haemoparasites in African buffalo (Syncerus caffer) from two wildlife areas in Northern Botswana. Parasit Vectors 2015; 8: 26.

5. Kang JG, Ko S, Kim YJ, Yang HJ, Lee H, Shin NS, Choi KS, Chae JS. New genetic variants of Anaplasma phagocytophilum and Anaplasma bovis from Korean water deer (Hydropotes inermis argyropus). Vector Borne Zoon Dis 2011; 11: 929-938.

6. Ko S, Kim SJ, Kang JG, Won S, Lee H, Shin NS, Choi KS, Youn HY, Chae JS. Molecular detection of Bartonella grahamii and B. schoenbuchensis-related species in Korean water deer (Hydropotes inermis argyropus). Vector Borne Zoon Dis 2013; 13: 415-418.

7. Shin GW, Kim EJ, Lee HB, Cho HS. The prevalence of Coxiella burnetii infection in wild Korean water deer, Korea. J Vet Med Sci 2014; 76: 1069-1071.

8. Harris RB, Duckworth JW. Hydropotes inermis. In: IUCN 2010. IUCN Red List of Threatened Species. Version 2010.1, 2008.

9. Kim BJ, Oh DH, Chun SH, Lee SD. Distribution, density, and habitat use of the Korean water deer (Hydropotes inermis argyropus) in Korea. Landscape Ecol Eng 2011; 7: 291-297.

10. Thompson JD, Gibson TJ, Plewniak F, Jeanmougin F, Higgins DG. The CLUSTAL_X windows interface: flexible strategies for multiple sequence alignment aided by quality analysis tools. Nucleic Acids Res 1997; 25: 4876-4882.
11. Saitou N, Nei M. The neighbor-joining method: a new method for reconstructing phylogenetic trees. Mol Biol Evol 1987; 4: 406425.

12. Page RD. TreeView: an application to display phylogenetic trees on personal computers. Comp Appl Biosci 1996; 12: 357-358.

13. Han JI, Jang HJ, Lee SJ, Na KJ. High prevalence of Theileria sp. in wild Chinese water deer (Hydropotes inermis argyropus) in South Korea. Vet Parasitol 2009; 164: 311-314.

14. Dumler JS, Choi KS, Garcia-Garcia JC, Barat NS, Scorpio DG, Garyu JW, Grab DJ, Bakken JS. Human granulocytic anaplasmosis and Anaplasma phagocytophilum. Emerg Infect Dis 2005; 11: 1828-1834.

15. Santos AS, Bacellar F, Dumler JS. Human exposure to Anaplasma phagocytophilum in Portugal. Ann N Y Acad Sci 2006; 1078: 100105.

16. Stuen S, Granquist EG, Silaghi C. Anaplasma phagocytophilum--a widespread multi-host pathogen with highly adaptive strategies. Front Cell Infect Microbiol 2013; 3: 31.

17. Perez M, Rikihisa Y, Wen B. Ehrlichia canis-like agent isolated from a man in Venezuela: antigenic and genetic characterization. J Clin Microbiol 1996; 34: 2133-2139.

18. Aktas M. A survey of ixodid tick species and molecular identification of tick-borne pathogens. Vet Parasitol 2014; 200: 276-283.

19. Ebani VV, Bertelloni F, Torracca B, Cerri D. Serological survey of Borrelia burgdorferi sensu lato, Anaplasma phagocytophilum, and Ehrlichia canis infections in rural and urban dogs in Central Italy. Ann Agric Environ Med 2014; 21: 671-675.

20. Andre MR, Dumler JS. Scorpio DG, Teixeira RH, Allegretti SM, Machado RZ. Molecular detection of tick-borne bacterial agents in Brazilian and exotic captive carnivores. Ticks Tick Borne Dis 2012; 3: 247-253.

21. Tateno M, Nishio T, Sakuma M, Nakanishi N, Izawa M, Asari $Y$, Okamura M, Maruyama S, Miyama TS, Setoguchi A, Endo Y. Molecular epidemiologic survey of Bartonella, Ehrlichia, and Anaplasma infections in Japanese Iriomote and Tsushima leopard cats. J Wildl Dis 2013; 49: 646-652.

22. Torina A, Blanda V, Antoci F, Scimeca S, D'Agostino R, Scariano E, Piazza A, Galluzzo P, Giudice E, Caracappa S. A molecular survey of Anaplasma spp., Rickettsia spp., Ehrlichia canis and Babesia microti in foxes and fleas from Sicily. Transbound Emerg Dis 2013; 60: 125-130.

23. Luo J, Yin H. Theileriosis of sheep and goats in China. Trop Anim Health Prod 1997; 29: 8S-10S. 
